\title{
A Heritage Local Language in Women's Refusal Acts: A Social Change in Verbal Expression From Ethnography Communication Perspective at Central Sulawesi
}

\author{
Fatma $^{1}$, Sumarlam ${ }^{2}$, S Suwandi ${ }^{3}$, and A Rakhmawati ${ }^{4}$ \\ ${ }^{1}$ STIE Panca Bhakti Palu, Sulawesi Tengah, Indonesia, \\ ${ }^{2-4}$ Universitas Sebelas Maret, Surakarta, Indonesia
}

kasimfatma24@gmail.com

\begin{abstract}
Female undergraduates' refusal speech is regarded as an independent perspective in the study of speech acts as a unit of communication. From the gender perspective and ethnography of communication, women language is included as a classic study on the variety of language that has different characteristic and specification as a gender marker. The local accent and dialect used by women in Central Sulawesi have unique trait when they are used in a conversation with local language as a heritage. This study aims to identify the form, strategy, and context for expressing refusal towards an instruction, invitation, request, and the others with a qualitative approach a sociopragmatics especially ethnography communication in the analyzing process. Substantively, the result shows that the form, strategy, and context for expressing refusal can be realized by using negation and requirement marker as well as by certain mode of refusal either it is direct or indirect. Topic and participant, as a part of the context, influence the women's choice of expression. As a verbal expression, refusal speech by women in the spoken academic discourse in Central Sulawesi is also influenced by the level of intimacy, sociocultural aspect, and multi-ethnical context, and social change.
\end{abstract}

Keywords: Heritage local language; refusal acts; social change; verbal expression, ethnography communication 


\section{INTRODUCTION}

In many countries with rich of local tradition like Indonesia, women have their own way to express refusal. Specifically, utterance used by women community has different choice of language to show the social change way compared to those used by men, including in expressing refusal [1]. This diversity of language is further used as a gender marker [2]. The specialness of women's refusal acts can also be seen in academic discourse context of female undergraduates in Central Sulawesi using a local language as a heritage language and language use. The variety of studies on speech acts in academic discourse becomes more important and interesting due to its continuity and synergy towards the previous study done [3]-[5]

In the international level, similar research which studies on speech acts, gender, and ethnography of communication has been done [6]-[9] as well as on wide and multi-context scope the past research [10]. The refusal acts on spoken academic discourse by the ethnicity of Kaili, Buginesse, and Manado in Central Sulawesi is shaped by the use of body language, sign language, implicit meaning, and the traits of the local accents and dialects themselves. The refusal acts is used by the women to express disagreement, unwillingness, reluctancy, or to do or not to do something. Thus, the variety of refusal acts viewed from gender, ethnography of communication, and the use of local accents are regarded as unique to be studied in this research.

Until now, several relevant research about gender, especially on the difference between men's and women's choice of languages is so many. It is proved simultaneously that research about discourse construct related to gender still becomes popular issue both in national and international levels. Some of the research is done by [11], who study about the gender difference on the use of academic discourse marker in Iran; and [12], about the difference of diction used by female and male undergraduates in Asia. Similarly, in Indonesia, gender is also studied. Some of the noticable research is conducted [13] who studies about language deviation on using men's choice of language by women as a form of resistance towards gender issue; [14], about gender study on intercultural society in France; and [15] about teacher's illocution viewed from gender and Javanese culture background.

This research is qualitative with the approach of SPEAKING (Scene, Participant, Ends, Act Sequence, Key, Instrument, Norms, and Genre) ethnography of communication by Hymes. Pragmatic, gender, and ethnographic views are used in this research to understand specific local conditions based on cooperative and politeness principles in which the female undergraduates use refusal acts. In this research, not all the eight factors are used to explain the problem. Communicative design, in the perspective of this research, is based on the use of language which contextually has meaning; and it is used to know the social communicative function [16]. The speech context pragmatically eases the language analysis process. This research emphasizes on the use of speech context which involves extra-linguistic include background social-culture, religion, genre, and linguistic context. The former refers to sociocultural aspect while the latter emphasizes on how language is used. [17], on their research, state that in order to realize the communication purpose, the speaker is encouraged to use strategy and interpretation in communication. Therefore, the implementation of ethnography of communication method and gender perspective is used to expound the cultural background and social norms, like level of education, gender, social status, intimacy, and the others; in the real situation. 


\section{METHOD}

This research is qualitative with the approach of SPEAKING ethnography of communication by Hymes. Pragmatic, gender, and ethnographic views are used in this research to understand specific local conditions based on cooperative and politeness principles in which the female undergraduates use refusal acts. In this research, not all the eight factors are used to explain the problem. Communicative design, in the perspective of this research, is based on the use of language which contextually has meaning; and it is used to know the social communicative function. The speech context pragmatically eases the language analysis process.

This research emphasizes on the use of speech context which involves extra-linguistic and linguistic context. The former refers to socio-cultural aspect while the latter emphasizes on how language is used. In this research, state that in order to realize the communication purpose, the speaker is encouraged to use strategy and interpretation in communication. Therefore, the implementation of ethnography of communication method and gender perspective is used to expound the cultural background and social norms, like level of education, gender, social status, intimacy, and the others; in the real situation.

This study focuses on the refusal acts delivered by female undergraduates viewed from gender by using speech acts theory through the identification of speech forms - declarative, imperative, and interrogative. The focus of the research is based on the view that any form of utterance can represent and express certain act either directly or indirectly [18].

\section{RESULT AND DISCUSSION}

The finding depicts diversity of refusal acts used by the female undergraduates towards their college friends. By the diversity, reflected the characteristics of choice of language used by the female undergraduates in refusing their male college friends' speech. Local languge in this context it means a heritage local language and identity from aspects social change in universities. In terms of language use, it can be inferred that both socio-cultural and situational context influence their speech and there is a code marker in intercultural academic context which reflects individual's style of communication and verbal conflict [19] This equilibrium becomes the basis to meet the purpose of communication since one can paraphrase their social dimension by using their own language or the other languages and referring to the linguistic structure or their own linguistic ability[20].

Utterance in the form imperative is a type of utterance that makes use of its real function. Briefly, [21] divides imperative sentence in Indonesian language into five classifications. They are (1) ordinary imperative sentence, (2) requesting imperative sentence, (3) permissive imperative sentence, (4) inviting imperative sentence, and (5) demanding imperative sentence. In relation to refusal acts of imperative sentence, the interlocutor prefers to order the speaker back [22]Refusal acts uttered by female speakers clearly shows refusal whether it is expressed through satire or other more understandable words. The use of satire in refusal acts is not intended to satirize. Instead, it is used to show care to the interlocutor and to create more comfortable situation so that fun conversation can take place [23], [24]In a different context [25] has been explored speech components used by female and male speakers' in the form of informal refusal, invitation, and request. 
Table 1. Kinds of Refusal Acts

\begin{tabular}{lll}
\hline \multicolumn{1}{c}{ Kinds of Refusal Acts } & $\begin{array}{c}\text { Honorific in Local } \\
\text { Language }\end{array}$ & \multicolumn{1}{c}{ Meaning } \\
\hline Refusal Acts by Ordering & $\begin{array}{l}\text { Ambil jo, kase akang, } \\
\text { baku ganti, dan } \\
\text { nyanda' }\end{array}$ & $\begin{array}{l}\text { Just take it, just give } \\
\text { it, take turns, and } \\
\text { no! }\end{array}$ \\
\hline Refusal Acts by Giving Comment & Deng, depe, dan katu' & $\begin{array}{l}\text { With, (his/her) } \\
\text { mine, yeah }\end{array}$ \\
\hline Refusal Acts by Satirizing & So, bemana? & Enough, How \\
\hline
\end{tabular}

The use of ethnography of communication in this research is connected to the local culture of Palu, Central Sulawesi. It is used to know the variety and strategy of delivering speech. It is also used to identify the female undergraduates' intention and purpose of communication based on the local culture which is then adjusted to non-formal situation in which they utter the expression[26]. Communicative situation is the extension of speech situation that is not only affected by the communicative principles, but also the context. The term context itself refers to eight factors governing the way of communication achieves its goal. The eight factors, according to [27]involve setting/scene, participant, ends, act sequence, keys, instrumentalities, norms of interaction, and genre.

Women are recognized by their grace, beauty, emotionalism, and care while men are perceived by their strength, rationality, manliness, and might. Form and various refusal act from women is a social change from phenomenon language use, especially with majorities local language in central Sulawesi, Kaili, Buginesse, and Malay Manado. The shift of characteristics and traits from time to time and from a place to another, or being different from one class to another, is called as the concept of gender. The expounding of characteristics and traits is exchangeable [28]. The concept of gender refers to the different characteristics of men and women shaped by society and culture. The gender marker is caused by many factors including social and cultural construct, empowerment, and socialization [29].

Such view on society causes marginalization on women not only in working place, but also in the house, society, and even culture. Gender is also a part of power and discourse in the social change. For [30], power and knowledge are important, especially in matter of that discourse and knowledge can be the means to gain power. Therefore, through the process of using knowledge, power has been implemented into various aspects like the social, ethnic, sexual, and religion domination. Linguistics and feminism view explain the gender difference on linguistic behavior. Feminism theory has been widely used by experts in studying the relation between language and gender [31]It is not only on the scope of society, but also on the level of discussion and the use of discourse which are used to comprehend the sole differences between men and women, especially in basic spoken refusal acts in power discourse context.

The difference of expression also occurs on the female undergraduates' choice of language as well. Choice of language used in refusal acts towards men's speech tends to be different than that is used to women's. The former tends to be vague, ironic, vary in expression, and indirect [32]. In the above dialogue, the speech of Interlocutor is a form of refusal acts shown by ordering Speaker back. The thing that can be the reference is the existence of imperative marker in Manado Language which is the word jo. Moreover, it is supported by speech act context. The context that underlies that refusal acts is the setting, topic, and participants. In their research findings, [33], [34] state that there are various languages that can be used in a speech act. Based on the context, the use of local language gives more pragmatics 
implication to Interlocutor. The use of local language shows Indonesian multilingualism means that can be retained to be used in informal communication without neglecting its good language structure. The same result too show that the people in the big city areas have aprobably factor also effect to use the among language [35].

At a glance, the above speech shows no intentional relation between speaker's and interlocutor's speech. However, based on the context that Speaker orders Interlocutor to sell the coupons left but Interlocutor orders Speaker back; Interlocutor indirectly refuse the order. In that dialogue, Speaker is a male undergraduate while Interlocutor is a female undergraduate. The refusal acts in that dialogue can be seen from the forms, strategies, and contexts of the refusal acts marked by negation marker nyanda', $n d a$, and te is mean no in english are not used independently in every refusal acts. The use of negation marker is more meaningful when they are used together with other words so that the form of refusal acts is different and special. Beside as among language, local language as a signified social culture and optimizing the identity [36].

\section{CONCLUSSION}

Potentially, as a kind of verbal expression, refusal acts is influenced by intimacy, sociocultural, academic context, and multiethnic context between the interlocutors. The forms, strategies, and contexts of female speakers' refusal acts are indicated by negation markers as nyanda'andte. Negation marker is equal with the word tidak in Bahasa and the word no in English. Generally, while the communication takes place, the female undergraduate faces informal situation. Therefore, the use of the word tidakis rare. The tendency to use the word tidak is simplified by using the nda. This shows how negation marker nyada' and nda' is used in refusal acts. Moreover, there is the use of honorific ki that means kita in Indonesian and we in English to respect older interlocutor which is Interlocutor though there is the same race and ethnic to express refusal acts between Speaker and Interlocutor. In addition, the topic and the participants involved in the communication influence the refusal acts chosen by female undergraduates.

\section{ACKNOWLEDGMENTS}

This research is fully supported by Ministry of Research, Technology and Higher Education, Directorate General of Higher Education, Ministry of Education and Culture, Republik of Indonesia (DRPM DIKTI), In accordance with Decree Number 2/E/KPT/2018 and Research Contracts Number.1136 / K9/ KT.03 /2018 for Fiscal Year 2018. Appreciation and achievement to my promotor and copromotor in Universitas Sebelas Maret, Surakarta,Indonesia always give a motivation. Expecially for the committee Team Work Pelatihan Menulis Jurnal Internasional Bereputasi II 2018 by ADOBSI so this research can be published.

\section{REFERENCES}

[1] M. Y. Al-rousan, N. M. Awal, and K. Salehuddin, "Compliment Responses Among Male and Female Jordanian University Students.," Gema online, vol. 16, no. 1, pp. 1934, 2016.

[2] A. Soler, "Aristotelian Philosophy, Influence of," in The Biographical Encyclopedia of Islamic Philosophy, Oliver Lea., London: Bloomsbury, 2015.

[3] K. Saddhono and F. Kasim, "The Form and Function of Local Language in Directive 
Speech Act at A University in Central Sulawesi," Ling. Cult., vol. 10, no. 1, p. 37, 2016.

[4] S. Fatma, Sumarlam, Suwandi and A. Rakhmawati, "Showing Respect in A Multicultural Society in Central Sulawesi: A Sociopragmatics Study on Directives Soeech Acts in A Local Language in University Academic Environment," Spec. Issue Ed. Pertanika J. Soc. Sci. Humanit., vol. 25, pp. 99-115, 2017.

[5] F. Kasim, "A cross-cultural and Intercultural of Indirectness Speect Act: The Use of Interference Local Language in Academic Discourse at Central of Sulawesi," IJPTE Int. J. Pedagog. Teach. Educ., vol. 1, no. 2, 2017.

[6] N. M. H. Nik Hashim, S. S. Alam, and N. Mohd Yusoff, "Relationship between Teacher's Personality, Monitoring, Learning Environment, and Students' EFL Performance," GEMA Online J. Lang. Stud., vol. 14, no. 1, pp. 101-116, 2014.

[7] C. H. Ying, H.S., Heng and A. . Abdullah, "Language Vitality of Malaysian Languages and Its Relation to Identity," Gema Online, vol. 152, pp. 119-136, 2015.

[8] P. L. Marshall, 'Using My 'You Lie Moment' to Theorize Persistent Resistance to Critical Multicultural Education," Int. J. Multicult. Educ., vol. 17, no. 2, p. 117, 2015.

[9] M. Kahn and P. C. Gorski, "The Gendered and Heterosexist Evolution of the Teacher Exemplar in the United States: Equity Implications for LGBTQ and Gender Nonconforming Teachers," Int. J. Multicult. Educ., vol. 18, no. 2, p. 15, 2016.

[10] C. H. Brock, A. Borti, T. Frahm, L. Howe, D. Khasilova, and K. Ventura-Kalen, "Employing Autoethnography to Examine Our Diverse Identities: Striving Towards Equitable and Socially Just Stances in Literacy Teaching and Research," Int. J. Multicult. Educ., vol. 19, no. 1, p. 105, 2017.

[11] M. T. Yeganeh and S. M. Ghoreyshi, "Exploring Gender Differences in the use of Discourse Markers in Iranian Academic Research Articles," Procedia - Soc. Behav. Sci., vol. 192, pp. 684-689, 2015.

[12] Y. Ishikawa, "Gender Differences in Vocabulary Use in Essay Writing by University Students," Procedia - Soc. Behav. Sci., vol. 192, pp. 593-600, 2015.

[13] Subandini, "Deviation of Male Language Use by Female Speakers as a Form of Reflection on the Condition of Mental Contrast to Gender Differences.," LENTERA, vol. 22, pp. 85-96, 2006.

[14] W. Udasmoro, "Discourse Subaltern in the Intercultural Society: Observing the Gender Relations of Hijab and Woman Headed in France," J. Soc. Polit. Sci., vol. 14, no. 1, pp. 1-22, 2010.

[15] A. Kentary, A., Ngalim and J. . Prayitno, "Teaching Teacher's Discourse Behind the Culture of Java," Gend. Perspect. Hum., vol. 16, no. 1, 2015.

[16] A. Mudiono, "Ethongraphic Study of Communication of Indonesian Assertive Illocution in Informal Education," J. Educ. Learn., vol. 18, no. 2, 2011.

[17] L. Van Praag, P. A. J. Stevens, and M. Van Houtte, "How humor makes or breaks student-teacher relationships: A classroom ethnography in Belgium," Teach. Teach. Educ., vol. 66, pp. 393-401, 2017.

[18] A. V Baydak, C. Scharioth, and I. A. Il'yashenko, "Interaction of Language and Culture in the Process of International Education," Procedia - Soc. Behav. Sci., vol. 215, pp. 14-18, 2015.

[19] P.-H. Lü, "When different 'codes' meet: Communication styles and conflict in intercultural academic meetings," Lang. Commun., vol. 61, pp. 1-14, 2018.

[20] J. F. Hamers and M. H. A. Blanc, Bilinguality and Bilingualism. Cambridge: Cambridge University Press, 2000.

[21] R. Kunjana, Imperative Politeness in Indonesian Language. jakarta: Erlangga, 2005. 
[22] R. E. Gildersleeve and S. Hernandez, "Producing (im)Possible Peoples: Policy Discourse Analysis, In-State Resident Tuition and Undocumented Students in American Higher Education," J. Multicult. Educ., vol. 14, no. 2, pp. 1-19, 2012.

[23] S. Fatma, Sumarlam, Suwandi and A. Rakhmawati, "Showing Respect in A Multicultural Society in Central Sulawesi: A Sociopragmatics Study on Directives Soeech Acts in A Local Language in University Academic Environment," Spec. Issue Ed. Pertanika J. Soc. Sci. Humanit., vol. 25, pp. 99-115, 2017.

[24] Z. M. Hassan, "Language Contextualisation and Culture," Procedia - Soc. Behav. Sci., vol. 136, pp. 31-35, Jul. 2014.

[25] Y. Nur, Expression of Refusal Speech in a Gender Perspective: A Theoretical Review. Malang: Surya Pena Gemilang Publishing, 2007.

[26] Y. Nur, Women's Language in Contextual: A Pragmatics Review. Malang: Surya Pena Gemilang Publishing, 2009.

[27] D. Hymes, Etnoghraphy, Linguistics, Narrative Inequality: Toward an Understanding of Voice. London: Taylor and Francis, 1996.

[28] M. Fakih, Gender Analysis and Social Transformation. Yogyakarta: Pustaka Pelajar, 2013.

[29] S. J. K. Gallena, B. Stickels, and E. Stickels, "Gender Perception After Raising Vowel Fundamental and Formant Frequencies: Considerations for Oral Resonance Research," J. Voice, vol. 32, no. 5, pp. 592-601, 2018.

[30] M. Foucalt, Power/Knowledge. Selected Interviewed and Other Writings, 1972-1977. New York: Phanteon Books, 1980.

[31] F. Ogunsiji, Y. and Adebiyi, "Language, Gender, and Culture," Br. J. Art Soc. Sci., vol. 6, no. 2, pp. 202-210, 2012.

[32] Y. Nur, "Mutual Understanding of Dialect Languages Kaili in Palu Central Sulawesi," Lingua, vol. 5, no. 2, pp. 105-111, 2013.

[33] H. Su, "Local grammars of speech acts: An exploratory study," J. Pragmat., vol. 111, pp. 72-83, 2017.

[34] B. Andi-Pallawa, "Function Words of Andio Language Viewed from Syntactical Aspect," Acad. J. Interdiscip. Stud., vol. 2, no. 2, pp. 175-89, Jul. 2013.

[35] K Saddhono and D Sulaksono, "Indoglish as adaptation of english to Indonesian: change of society in big cities of Indonesia," in IOP Conference Series: Earth and Environmental Science 126 (2018) 012092, 2018.

[36] K. Saddhono, A. Rakhmawati, and S. Hastuti, "Indoglish Phenomenon: The Adaptation of English Into Indonesian Culture," Int. Sci. Res. J., vol. 72, no. 3, pp. 29-35, 2016. 